DOI 10.31558/2307-2318.2021.1.10

УДК 338.124.4:616.98

JEL: B22, C45, C53, C81, D82

Солоненко Ю. В.

к.е.н., доцент кафедри підприємництва, корпоративної та просторової економіки, Донецький національний університет імені Василя Стуса

ORCID: 0000-0003-1696-2151

u.solonenko@donnu.edu.ua

Говоруха М. Р.

здобувач, Донецький національний університет імені Василя Стуса

ORCID: 0000-0002-9214-9333

hovorukha.m@donnu.edu.ua

\title{
ШЛЯХИ ПОДОЛАННЯ АСИМЕТРИЧНОЇ ІНФОРМАЦІЇ ПІД ЧАС ПОБУДОВИ ТОЧНИХ МОДЕЛЕЙ ПАНДЕМІЙ
}

У статті обтрунтовано об'єктивну необхідність удосконалення існуючих моделей прогнозування моделей пандемій, виділено основні фактори вирішення проблем асиметрії. Виявлено залежність між рівнем стурбованості, кількістю інтернет-запитів в мережі Інтернет та недотриманням карантинних заходів. Авторами доведено небезпеку нескоординованих та неквапливих дій на історичному прикладі пандемії, щьо мала назву «іспанка». Для загального розуміння теми схематично відображено дію механізму штучних нейронних мереж, побудовано модель прогнозування епідемії SIR. Практичне значення роботи полягає в тому, що більш точні моделі прогнозування перебігу пандемій можуть врятувати мільйони життів та забезпечити стабільні системи економічного, соціального та політичного життя населення. Подолання неповноти та неточності інформації дозволить керівникам держав не допускати помилок при прийнятті важливих рімень. Подальші дослідження в обраній темі даватимуть змогу отримувати точні дані про перебіг епідемій, а в перспективі - допоможуть подолати проблему асиметрії інформачії.

Ключові слова: асиметрична інформація, епідемія, пандемія, модель SIR.

Puс. - 4, літ. - 9.

Постановка проблеми. Асиметрія отриманої інформації викликає у учасників пандемічних процесів постійний дисонанс. Нейтралізація можлива за умови часткової або ж повної ліквідації факторів, що впливають на інформаційне наповнення існуючої проблеми. Формування уявлень, що не відповідають дійсності може спровокувати хвилі істерії та протестів серед населення у випадку відображення статистики, вищої за реальну, або викликати невідповідальне ставлення до карантинних заходів зворотному випадку. I те, і інше погіршить фізичний та психологічний стан здоров'я населення в умовах необхідності дотримання спокою та чітких вказівок держави.

Аналіз останніх досліджень і публікацій. Науковими дослідженнями 3 даної тематики та проблем, які виникають під час подолання асиметричної інформації, займались такі закордонні та вітчизняні вчені як: Джозеф Стігліц, Джордж Акерлоф і Майкл Спенс, Валентина Мазуренко, Віталій Огієнко, Наталія Мацелюх та Володимир Міловідов. 
Питаннями прогнозування пандемії займалися відомі дослідники Андерсон Кермак i Уільям Маккендрік, які створили модель епідемій SIR, що базувалась на математичному аналізі.

Грунтуючись на проведеному аналізі робіт, видно, що дослідження, як вітчизняних, так і зарубіжних науковців, висвітлюють окремо питання асиметрії інформації та побудови моделей епідемій. Проте не існує досліджень, присвячених темі необхідності побудови моделей розвитку пандемій з урахуванням інформаційної асиметрії.

Метою дослідження $\epsilon$ визначення сутності асиметричної інформації, розробка загальної методики побудови моделей пандемій в умовах асиметричної інформації для подальшого можливого використання в процесі аналізу ефективності дій з усунення спалахів захворювань.

Формулювання цілей дослідження. Враховуючи викладене, автори сконцентрували увагу на обгрунтуванні об'єктивної необхідності вдосконалення існуючих моделей та шляхах вирішення проблеми асиметричної інформації при побудові моделей поширення пандемій.

Виклад основного матеріалу. Інфекційні хвороби $є$ основною причиною смерті у всьому світі, через них загинуло набагато більше людей, ніж через усі війни [1]. Математичне моделювання інфекційних хвороб було започатковано Даніелем Бернуллі в 1760 р. Робота Андерсона Кермака і Уільяма Маккендріка, опублікована в 1927 р., мала великий вплив на структуру моделювання поширення хвороб. Їх модель SIR досі використовується для моделювання епідемій інфекційних захворювань. Модель SIR (Susceptible - Infected Recovered) в основі якої лежить математичний апарат диференціальних рівнянь для неперервного часу та різницевих рівнянь для дискретних значень дає змогу своєчасно скласти та оцінити план проведення вакцинації і карантинних заходів, що дозволяє знизити кількість хворих і рівень смертності від захворювань [2]. Моделювання поширення інфекційних захворювань $\epsilon$ інструментом, що на основі вивчення механізму епідемії, дозволяє передбачати нові спалахи захворювання і оцінювати стратегію боротьби 3 ним. Використання діючої моделі у випадку прогнозування динаміки пандемій передбачає групування населення відповідно до статусу: сприйнятливі до захворювання, заражені і ті, що одужали. Виділені групи постійно переходять із стану в стан, «перетікаючи» між накопичувачами, поки епідемія не закінчиться (рис. 1).

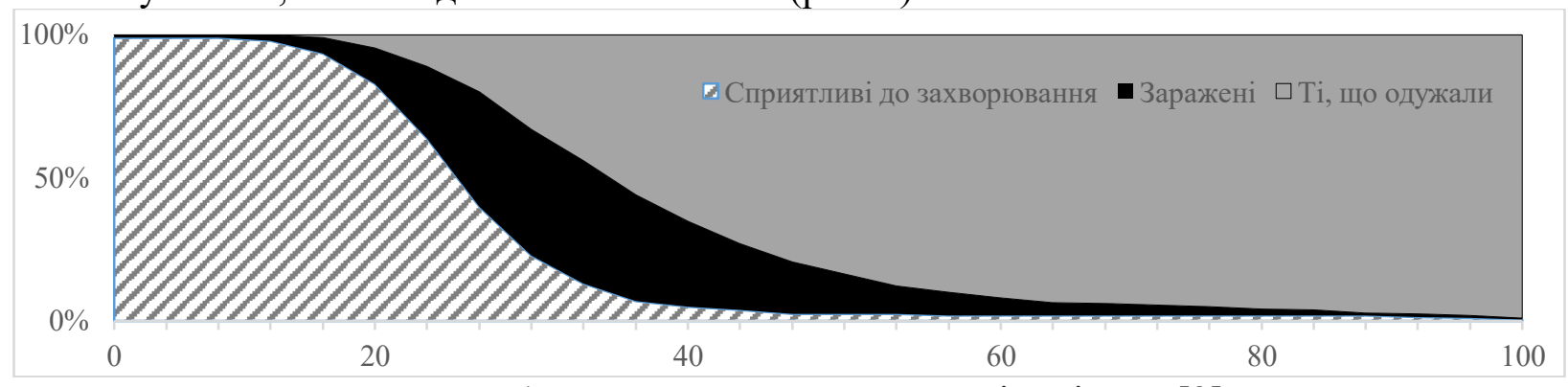

Рисунок 1. Модель прогнозування епідемії SIR [3]

3 рисунку 1 видно, що чисельність популяції вважається постійною. Таким чином, в моделі не враховуються демографічні процеси, такі як народжуваність, смертність та міграція індивідів. Це спрощення вважається коректним в силу того, що порівняно 3 життям індивідів епідемія швидкоплинна. У моделі Кермак-Маккендрік кількість знову інфікованих в популяції підпорядковується «закону діючих мас»: вона прямо-пропорційна добутку поточної чисельності сприйнятливих і інфікованих. У ряді випадків при моделюванні епідемій більш придатним є припущення, що сила інфекції залежить не від абсолютної 
кількості інфікованих в популяції, а від відносної. Хвороба поширюється в міру того, як ті, хто вступає в інфекційний контакт, передають хворобу сприйнятливим та одужують, закінчуючи цикл протікання хвороби. Швидкість цього переходу залежить від параметрів моделі, зокрема від частоти контакту, інфекційності та середньої тривалості хвороби.

Світові пандемії часто мають складні цикли розвитку (рис. 2). Пандемія «іспанки» складалася $з$ трьох великих хвиль, що були зумовлені, в великій вазі, невідповідальним відношенням глав держав. Дії, подібні до наказу про репатріацію військ на батьківщину, недотримання карантину, ізоляції міст та країн, призвели до повторних спалахів захворювання.

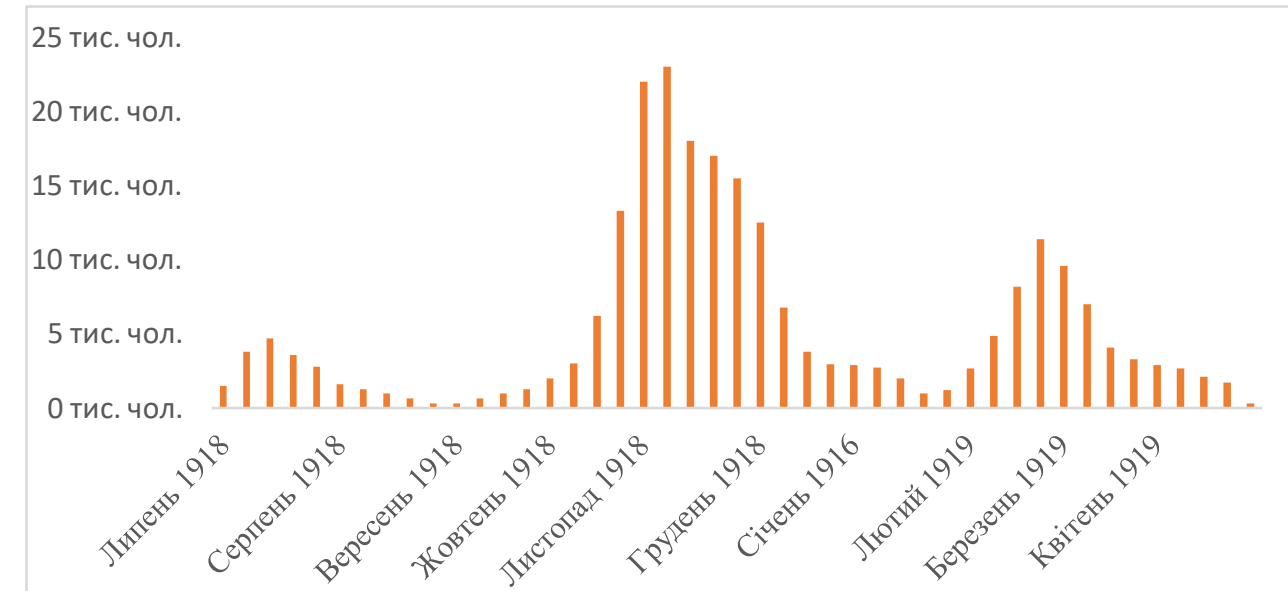

Рисунок 2. Число інфікованих під час пандемії «іспанки» в 1918-1919 рр. в Об’єднаному Королівстві, тис. чоловік (рисунок побудований за даними [4])

Вчені Массачусетського університету виявили, що американські міста, які робили зусилля по скороченню контактів між людьми на початку спалаху «іспанки» 1918 року, мали нижчі пікові показники смертності (358 смертей на 100 тисяч населення в Сент Луісі), ніж міста, які взяли курс на політику карантину пізніше (710 смертей від зараженння на 100 тисяч населення в Бостоні) [5]. Поінформованість громадян була фактором, що знижував швидкість поширення пандемії за рахунок усвідомлення суспільством ключових дій та рольових поведінок під час епідемії. При необхідності приділення більшої уваги до фактору випадковості та ймовірності, викликаного збільшенням ваги асиметричної інформації, стає все важче точно передбачити майбутні епідемічні хвилі за допомогою обрахунків, що базуються на простому математичному аналізі.

Теорія інформаційної асиметрії - це теорія, яку розробили американські вчені Джордж Акерлоф, Майкл Спенс та Джозеф Стігліц в рамках інформаційної економіки на основі аналізу ринків та управління фінансами корпорацій. ІІЇ суть полягає в тому, що нерідко учасники економічних процесів володіють нееквівалентною кількістю інформації про об'єкти інтеракцій і за рахунок цього мають інформаційну перевагу над іншими [6]. Як стверджує професор економіки Колумбійського університету, лауреат Нобелівської премії з економіки Джозеф Стігліц, «протягом двохсот років економісти використовували прості економічні моделі, побудовані на припущенні про повноту і точність інформації, тобто на тому, що всі зацікавлені сторони володіють ідентичною загальнодоступною інформацією 3 певного питання. При цьому було зрозуміло, що сказане не відповідає дійсності, але усі сподівалися, що наявністю невеликих інформаційних неточностей можна знехтувати, приймаючи повноту інформації за аксіому» [7]. Хибність такого підходу полягає в тому, що в ринковому середовищі вплив навіть незначних, на перший погляд, чинників, можуть суттєво впливати 
на розвиток економіки. Значно більшу небезпеку становить інформаційна асиметрія в галузі охорони здоров'я. Вона по-різному проявляється при наданні звітів та медичних послуг в державній, змішаній та приватній системі охорони здоров'я і пов'язана, в основному, 3 механізмом фінансування, способом оплати праці виробників послуг і методом оплати медичної допомоги споживачами, проте завжди повинна перевірятися та контролюватися діяльністю держави. Асиметрія інформації за умови іiі посилення стає однією з головних проблем в сфері охорони здоров'я, що заважає вийти на суспільно ефективні рівні витрат, обсягів, якості медичної допомоги. Це дає додатковий аргумент на користь посилення заходів, спрямованих на підвищення прозорості показників, обробку інформації про діяльність системи, і на подальші більш детальні оцінки причинно-наслідкових залежностей.

3 вищенаведених фактів та міркувань постає однозначна важливість та необхідність вирішення проблеми асиметричної інформації під час побудови моделей інфекційних захворювань. Таким чином можливо відокремити наступні фактори вирішення проблем асиметрії:

- Інноваційний. Формування більш повної та досконалої інформації для передбачення перебігу пандемій можливе за допомогою введення в модель прогнозування додаткових параметрів, зокрема параметру дотримання карантинних заходів. Відслідковування непрямих ознак виконання та нехтування рекомендаціями держави щодо тимчасового обмеження пересування покращить точність прогнозів та допоможе в отриманні більш широких даних для побудови моделей пандемій. Серед ознак, що можуть опосередковано характеризувати інтенцію та настрої населення: масовість інтернет-запитів громадян на певну тематику, активність пересування містом та густонаселеними регіонами. Сервіси Google Trends, AppleMaps та Google Maps надають таку інформацію в узагальненій формі. Оскільки інформація є неперсоніфіковою, то вона не порушує особисті свободи окремих осіб. На рис. 3 зображена динаміка активності українців під час виходу країни на карантин. Рисунок показує, що в середині березня кількість піших та автопрогулянок в Україні зменшилася в два рази.

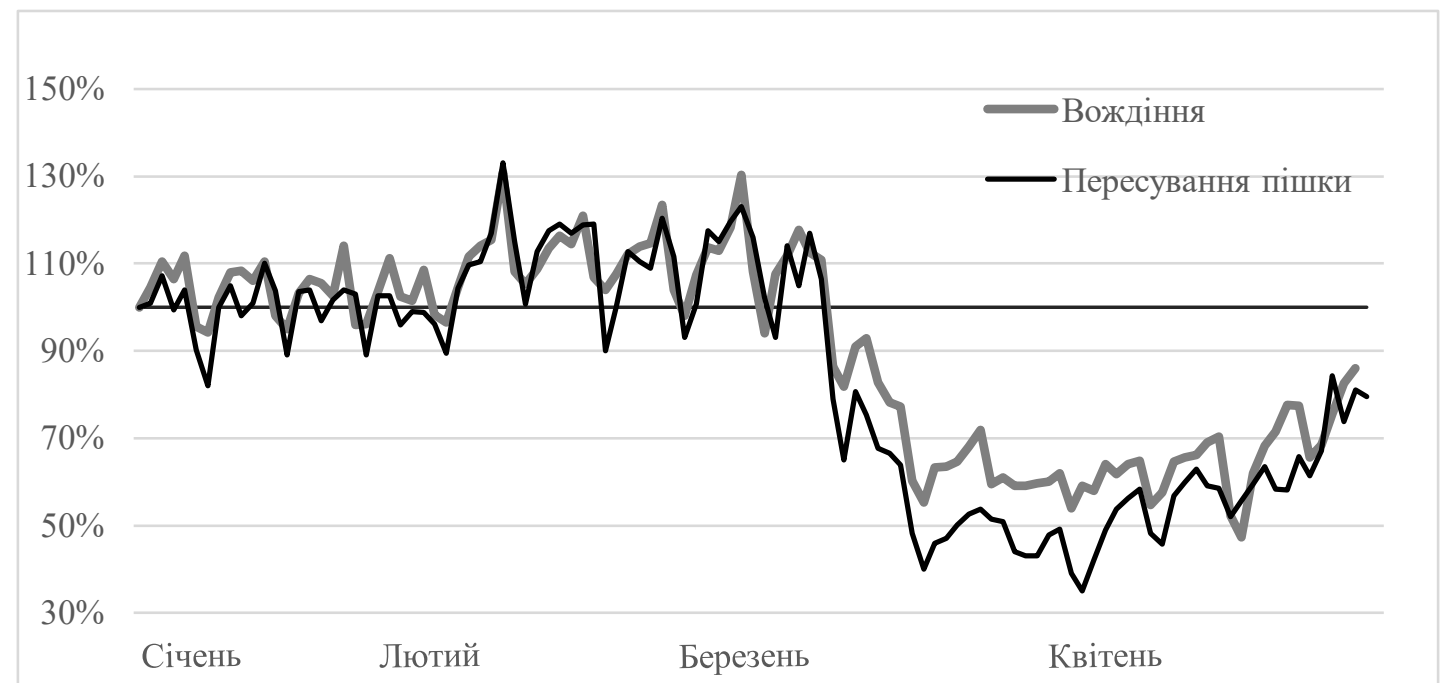

Рисунок 3. Динаміка активності українців у січні-квітні 2020 року, \% (рисунок побудований за даними [8])

Дослідження взаємозв'язку між місцевою активністю та дотриманням карантинних заходів, вивчення щільності кореляції між ними допоможе в наданні необхідної інформації 
правоохоронним органам для подальшого здійснення превентивних заходів на локальному рівні та в перевірці правдивості даних, що надаються іншими країнами.

- Статистичний. Прозорість отримання результатів тестів та збільшення їх кількості може частково вирішити проблему неповноти інформації для держави та громадян. Приведення звітів в єдиний формат показників забезпечить порівняння даних різних країн та епідемій. Згруповані по одному зразку масивні дані легше піддаються співставленню та агрегуванню, а надалі, - i аналізу із виведенням закономірностей. Створення систем контролю звітності, особистих кабінетів або серійних номерів для інфікованих, стандартизація існуючих факторів - це ті форми перевірки даних, що забезпечать достовірність офіційної статистики.

- Аналітичний. Метод полягає в створенні систем стандартних, базових рішень та концепцій, що забезпечать швидкість реагування на нові спалахи хвороб, перевірку несуперечливості наданих даних. Фактор спрямований на визначення внутрішніх тенденцій які виникають в однакових та різних умовах і можливостей для більш ефективного реагування в поінформованому середовищі. Використання практики інших країн дозволить заощадити час та ресурси на збір та опрацювання нових знань. Створення заготовлених рішень для шаблонних ситуацій допоможе відновлювати відсутню інформацію та передбачати наслідки.

- Технологічний. Важливим методом, що опирається на машинне навчання, $\epsilon$ використання штучних нейронних мереж (ШНМ). Методологія ШТМ широко відома і добре підходить для вирішення задач, аналітичне дослідження яких має складну структуру. ШНМ це спрямований зважений граф, вершини якого моделюють функціонування біологічних нейронів, див. рис. 4. Вони приймають вхідні сигнали і при досить великому значенні їх зваженої суми перетворять їх в вихідний сигнал. Формального підходу до вибору характеристик ШНС не існує, в переважній більшості випадків використовуються мережі прямого поширення сигналу і алгоритм зворотного поширення помилки [9].

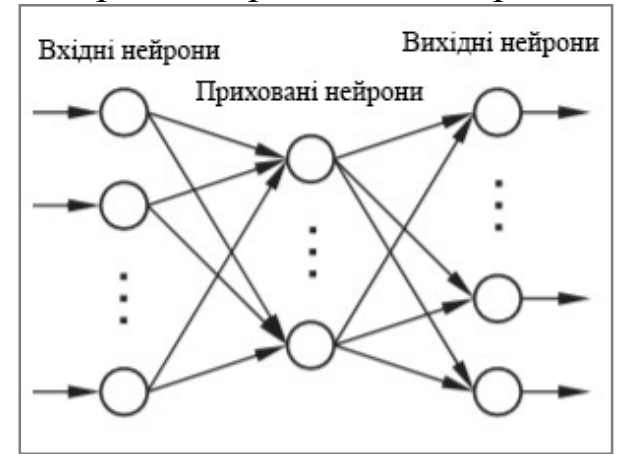

Рисунок 4. Схема ШТМ з одним прихованим шаром [9]

Однією з цілей навчання ШТМ є визначення явних і неявних залежностей між вхідними та вихідними даними. Навчання ШНС полягає в обчисленні коефіцієнтів зв'язків між вершинами, що визначають силу вхідних сигналів, і виконується на основі емпіричних даних: статистики захворюваності і при наявності, значень факторів, які іï зумовлюють. Показники захворюваності, як правило, зашумлені, тому для навчання ШНМ потрібно порівняно велика їх кількість. Існує безліч варіантів застосування ШНМ для прогнозування захворюваності: ШНМ можуть відрізнятися архітектурою, кількістю нейронів і видом функцій їх активації, способом навчання. Використання штучного інтелекту дозволяє збільшити обсяги зібраної інформації. Здобутки прогресу в сфері машинного навчання дозволять розрізняти хворобу за описом іï симптомів (наприклад грип від COVID-19) та зможе перешкоджати формуванню недостовірної статистики. 
Висновки. Авторами було запропоновано нову класифікацію факторів, введення яких в моделі прогнозування перебігу епідемій допоможуть у вирішенні проблеми асиметрії інформації, серед них: інноваційний, економічний, статистичний, технологічний. Дана робота грунтовно доводить тезу, про необхідність вдосконалення теоретичної бази теми побудови точних моделей пандемій, потребу в введенні нових змінних в існуючі моделі прогнозування перебігу епідемій та в нових шляхах їх відслідковування задля подолання проблеми асиметрії інформації. Важливим є створення систем контролю за правильністю подачі даних, що стосуються перебігу захворювань, єдиних норм звітності та ефективних методів її збору. Застосування новітніх технологій допоможе охоплювати більші об'єми спостережень, що в перспективі створить велику базу шаблонних та зразкових вирішень типових задач.

\section{СПИСОК ВИКОРИСТАНИХ ДЖЕРЕЛ}

1. ETH Zurich. Theoretical Biology : веб-сайт. URL: https://tb.ethz.ch/

2. Kermack W. and McKendrick A. A contribution to the mathematical theory of epidemics. Proc. R. Soc. London, 1927. 700-721 p.

3. AnyLogic simulation software : веб-сайт. URL: https://cloud.anylogic.com/

4. Супотницкий М. В. Пандемия «испанки» 1918-1920 гг. в контексте других гриппозных пандемий и «птичьего гриппа». Медицинская картотека. 2006. № 11. С. 31-34.

5. National endowment for the numanities : веб-сайт. URL: https://www.neh.gov/humanities/2014/marchapril/feature/the-devastation-1918

6. The Noble Prize : веб-сайт. URL: https://www.nobelprize.org/prizes/economicsciences/2001/popular-information/

7. Загородній А.Г. Асиметрія інформації між учасниками реалізації інноваційного проекту та шляхи їі усунення. Економіка: реалії часу. Львів. 2016. С. 6-14.

8. AppleMaps Mobility Trends : веб-сайт. URL: https://www.apple.com/covid19/mobility

9. Кондратьев M. А. Методы прогнозирования и модели распространения заболеваний. Компьютерные исследования и моделирование. Санкт-Петербург. 2013. № 5, т. 5. С. $863-882$.

10. Солоненко Ю.В. Особливості формування сімейного бізнесу України у системі європейських координат. Вісник Донеиького наџіонального університету. Серія В. Економіка і право. Вінниця: ДонНУ, 2015. Вип. 1. С. 332-335.

\section{REFERENCES}

1. ETH Zurich. Theoretical Biology : website. URL: https://tb.ethz.ch/

2. Kermack W. and McKendrick A. (1927). A contribution to the mathematical theory of epidemics. Proc. R. Soc. 700-721.

3. AnyLogic simulation software : website. URL: https://cloud.anylogic.com/

4. Supotnytskyi M. V. (2006). Pandemyia «yspanky» 1918-1920 yy. v kontekste druhykh hryppoznykh pandemyi y «ptycheho hryppa». Medytsynskaia kartoteka. № 11. 31-34.

5. National endowment for the numanities : website. URL: https://www.neh.gov/humanities/2014/marchapril/feature/the-devastation-1918

6. The Noble Prize : website. URL: https://www.nobelprize.org/prizes/economicsciences/2001/popular-information/

7. Zahorodnii A.H. (2016). Asymetriia informatsii mizh uchasnykamy realizatsii innovatsiinoho proektu ta shliakhy yii usunennia. Ekonomika: realii chasu. 6-14.

8. AppleMaps Mobility Trends : website. URL: https://www.apple.com/covid19/mobility 
9. Kondratev M. A. (2013). Metods prohnozyrovanyia, modely rasprostranenyia zabolevanyi. Kompiuternыe yssledovanyia y modelyrovanye. № 5, t. 5. 863-882.

10. Solonenko Yu. V. (2015). Osoblyvosti formuvannia simeinoho biznesu Ukrainy u systemi yevropeiskykh koordynat. Visnyk Donetskoho natsionalnoho universytetu. Seriia $V$. Ekonomika i pravo. Vyp. 1. 332-335.

Солоненко Ю. В., к.э.н., доцент кафедры предпринимательства, корпоративной и пространственной экономики, Донецкий национальный университет имени Васыля Стуса

Говоруха М. Р., Донецкий национальный университет имени Васыля Стуса

\section{ПУТИ ПРЕОДОЛЕНИЯ АСИММЕТРИЧНОЙ ИНФОРМАЦИИ ПРИ ПОСТРОЕНИИ ТОЧНЫХ МОДЕЛЕЙ ПАНДЕМИЙ}

В статье обоснована объективная необходимость совершенствования существующих моделей прогнозирования моделей пандемий, выделены основные факторы решения проблем асимметрии. Выявлена зависимость между уровнем обеспокоенности, количества интернет-запросов в сети Интернет и несоблюдением карантинных ограничений. Авторами доказано опасность нескоординированных и неторопливых действий на историческом примере пандемии, под названием «испанка». Для общего понимания темы схематично отражено действие механизма искусственных нейронных сетей, построена модель прогнозирования эпидемии SIR. Практическое значение работы состоит в том, что более точные модели прогнозирования протекания пандемий могут спасти миллионы жизней и обеспечить стабильные системы экономической, социальной и политической жизни населения. Преодоление неполноты и неточности информации позволит руководителям государств не допускать ошибок при принятии важных решений. Дальнейшие исследования в выбранной теме дадут возможность получать точные данные о ходе эпидемий, а в перспективе - помогут преодолеть проблему асимметрии информации.

Ключевые слова: асимметричная информация, эпидемия, пандемия, модель SIR.

Y. Solonenko, $\mathrm{PhD}$ in Economics, Associate Professor of the Department of Entrepreneurship, Corporate and Spatial Economics, Vasyl Stus Donetsk National University

M. Hovorukha, Vasyl' Stus Donetsk National University

\section{WAYS TO OVERCOME ASYMMETRIC INFORMATION IN BUILDING ACCURATE PANDEMIC MODELS}

The article substantiates the objective need to improve the existing models for predicting pandemic models, identifies the main factors for solving asymmetry problems. A relationship was revealed between the level of concern, the number of Internet requests on the Internet and noncompliance with quarantine restrictions. The authors have proven the danger of uncoordinated and unhurried actions on the historical example of a pandemic called "Spanish flu". For a general understanding of the topic, the action of the mechanism of artificial neural networks is schematically reflected, a model for predicting the SIR epidemic is built. The practical significance of the work lies in the fact that more accurate models for predicting the course of pandemics can save millions of lives and provide stable systems for the economic, social and political life of the population. Overcoming the incompleteness and inaccuracies of information will allow the leaders of states to avoid mistakes when making important decisions. Further research in the chosen topic will make it possible to obtain accurate data on the course of epidemics, and in the future, will help to overcome the problem of information asymmetry.

Keywords: asymmetric information, epidemic, pandemic, SIR Model for spread of disease. 